\title{
TYPES OF BANK LOANS AND THEIR IMPACT ON ECONOMIC DEVELOPMENT: A CASE STUDY OF THE CZECH REPUBLIC
}

\author{
Jan Černohorský
}

\section{Introduction}

In this article, we discuss the relationship of banks, or loans provided by them, and economic development. We decided to investigate this relationship as banks in today's economies play a significant role as a vital institution in the financial markets, where there is a distribution of monetary funds from surplus entities to deficit entities. A necessary precondition of a functioning economy, in its present mostly mixed form, is a functioning and stable banking system. Currently, uncovered money is to a great extent the money generated by private banks, mainly in the form of loans.

In these turbulent times, when economies are growing and declining at faster intervals than were customary in previous decades, this is very much a contemporary issue. It is due to the fact that the rate of growth/decline in lending, due to the importance and size of the financial markets and the form of the uncovered money issued, significantly influences the economic cycle. As reported by Černohorský (2015), banks provide loans to businesses and households for their consumption and investment and thus support the economy. What is important is the duration of a loan, as particularly long-term investments contribute to long-term economic growth. For this reason, we decided to examine the impact of total loans, as well as dividing them into loans to non-financial businesses, loans to households, mortgage loans and consumer loans. The importance of credit access to banks is also compounded by the financial and economic crisis which most of the developed countries experienced in recent years. The consequence of this crisis today is an abnormal situation on the financial markets, which is reflected in negative interest rates, foreign exchange intervention and quantitative easing by central banks. They are trying to use these unconventional monetary policies to restore the impaired credit channel of the monetary policy transmission mechanism.

The main idea of this article is expressed by the hypothesis that the development of various types of bank lending has a positive effect on economic development. We will examine the validity of this hypothesis using selected statistical and mathematical methods as presented below.

The aim of this article is to assess the impact of the development of different types of loans in the banking sector on economic development, based on the example of the Czech Republic. In achieving this set goal, we shall begin with the hypothesis that economic performance increases with the growth of the rate of various types of loans.

\section{Theoretical Background}

In the past, the relationship of the financial system and economic growth was examined by a number of renowned economists. Schumpeter (1912) emphasised the strong influence of banks on economic growth by encouraging innovation. Providing loans for these innovations and investments leads to the growth of business operations and thus to economic growth. In contrast, Lucas (1988), in more modern times, refers to an excessive influence of banks on the economy in a negative sense. Robinson (1952) considers that banks have a passive impact on economic development. As can be seen, even in the past these distinguished economists held different views on the impact of the banking sector on economic development. It is still the same today, as evidenced by subsequent research.

Our paper is based on the transmission mechanism of monetary policy as it is understood both in economic theory and applied in practice in the enforcement of monetary policy by central banks. In particular, 
we follow the logic of the credit channel of the monetary policy transmission mechanism. This is based on the change in the interest rates set by the central bank, which affect interbank interest rates and in the end also the market interest rates offered to clients. If we consider declining interest rates, this results in a higher demand for loans from banks by companies and households. These loans are used for corporate investment and household consumption (or from a macroeconomic point of view also for investments through the purchase of real estate). At the same time, the amount of money in circulation is growing. The increase in consumption and investment thus contributes to the growth of the economy. In the case of increasing interest rates, the change in the given variables is the opposite or it may, for example, result not only in a decrease, but also in a decline in the growth rate, of the given quantities. A definite factor in support of this process is the central banks monitoring and striving to influence the rate of lending to a certain extent in order to support economic growth or to ensure that the economy doesn't get overheated.

The effect of the amount of money issued as bank loans on economic development is highlighted by the main proponent of monetarism, Milton Friedman (1968). As well, Friedman and Schwartz (1963) came to the conclusion that the correlation coefficients between the change in money and the nominal output range from 0.79 to 0.92 per survey period. They quantify the time delays in the effectiveness of monetary policy in a range of 12-24 months, with the maximum growth in the amount of money being in advance of 18 months ahead of the peak of economic growth. The minimum amount of money growth, according to his calculations, will be reflected in the economy in the form of a recession earlier, with an interval of approximately 12 months. Also, the money supply is understood as an autonomous exogenous quantity given by the central bank, which affects other macroeconomic variables.

The logic of this approach is supported by Miskhkin (2016), who, in addition to the credit channel, also defines other channels of monetary policy action. Kaufmann and Kugler (2010) also estimate real GDP on the basis of the development of $\mathrm{M} 3$, including the aspect of cointegration of the given variables. This idea is supported by Holtemöller (2004), who sets the time delay of the monetary policy tools on product changes at six quarters. For this he uses integration and cointegration analysis.

Currently, the connection between bank performance (measured, for example, in the form of lending rate) and economic performance is much closer. This is due to the enormous scale of globalised and also local financial markets due to the size of the economies and their impact on business activities. Today there is a higher degree of interconnectivity of financial markets and economic development. The final proof is certainly the financial crisis in the USA. It developed primarily in the banking sector and spilled over into a public finance crisis and an economic downturn in the economically important countries in the world and Europe. Therefore examining the relationship between bank lending and economic development has gained importance. Among the various works various indicators of lending are used to measure economic performance.

These contributions can be divided into three basic groups. The most significant in terms of numbers is the group of economists who believe in the positive impact of bank loans on economic development. Levine and his coeconomists in their works (Levine \& Zervos, 1998; Beck, Levine, \& Loayza, 2000; Beck \& Levine, 2004) examined various combinations of the effects of the liquidity of stock markets and banks (collectively, financial intermediation) on economic growth, capital accumulation and increased productivity. All the above, according to the authors, is positively influenced by the activities of banks. Armeanu et al. (2015) tested the effects of credit expansion on sustainable economic growth. They see a greater effect with loans to legal entities rather than to natural persons. The importance of loans to legal entities (companies) acts over a longer period, because their investments lead to further growth. Banu (2013) focused on the question of whether an economy, specifically the Romanian economy, would be capable of economic growth in the absence of lending. Without the loans provided to the private sector, the Romanian economy would not grow, as no new projects would arise. Conversely, very low dependence was found between loans to the public sector and economic growth. Kelly et al. (2013) began with a range of data from 10 years for the economy of Ireland, which was significantly affected 
by the financial crisis specifically because of the banking sector. Despite this significant fluctuation, Kelly finds a positive impact of lending activities on growth in the economy. As well, Ermisoglu et al. (2013) investigated whether data on loans would be an appropriate forecast for the development of gross domestic product (GDP). They stressed the importance of loan data in terms of a minimum delay. Again, they found a positive effect; i.e., they state that using the variable "credit incentives" in GDP prediction models increases their accuracy.

The results of a further study by Cetorelli and Gamber (2001) show that the banking sector facilitates access to credit for "young" firms, thereby supporting the pace of economic growth, as investments by new firms are more likely to be involved in innovative technologies. Bencivenga and Smith (1993) conclude that the banking sector can also reduce excessive credit limitation through reduced monitoring costs and thus ensure accelerated economic growth in a country. Levine (2005) shows the link between the operation of the financial system and economic growth.

On the other hand, there are studies that show a negative relationship between bank loans and economic development as measured by GDP growth. Leitao (2012) came to this conclusion based on an analysis of macroeconomic variables (economic growth, trade balance and inflation) and bank loans. $\mathrm{He}$ concluded that inflation is negatively correlated with economic growth. The main idea behind the study is that excessive credit growth tends to weaken a banking system and increase inflationary pressures, thereby undermining economic growth. Mian et al. (2015) based their study on an analysis of the relationship between household debt and GDP. According to their results, the growth of household debt in relation to GDP predicts a lower growth in production and higher unemployment rates in the medium term. As well, an increase in household debt will result in consumption growth and worsening current account balances as a result of the increased import of consumer goods. Koivu (2002) published a study based on data from 25 transitional economies in the years 1993-2000. In his work, he concluded that an increase in lending does not accelerate economic growth. The causes are a series of banking crises in these economies and fiscal restraint. He also stressed that these results are non-standard with economic findings primarily due to specific conditions in transition economies. IbáñezHernández et al. (2015) came to the conclusion that the high growth in lending leads to instability in the financial sector and thus negatively affects economic development.

There are also studies that do not indicate any significant relationship between the loans provided and economic growth. For example, Takats and Upper (2013) investigated the effect of bank loans on economic growth after the financial crisis on the basis of data from 39 financial crises that had been preceded by a credit boom. They found that a declining amount of bank lending to the private sector does not necessarily hinder economic recovery after a financial crisis. In these crises, changes in the rate of bank lending, either in real terms or in relation to GDP, do not correlate with growth during the first two years of recovery. In the third and fourth year, the relationship becomes statistically significant, but still remains insignificant in economic terms. De Gregorio and Guidotti (1995) found a positive correlation between the growth rate of bank loans to the private sector and the growth of GDP, but the impact varies in different countries. In Latin American countries, the relationship is actually negative. Their rationale was the recent financial liberalisation in these markets combined with a poor level of regulatory framework. They also emphasise that the main method whereby the growth of lending affects economic growth is primarily that these loans must be provided for effective projects; i.e., not a critical amount of these loans.

Based on the list mentioned above, it is clear that studies are prevalent which confirm the logic of the credit channel of the monetary policy transmission mechanism and show a positive relationship between the growth of lending and the growth of the economy. This corresponds to the current prevailing theoretical knowledge of bank contributions through money issuance by providing bank loans to grow the economy.

As well, we are aware of the interdependence of the effects of bank loans and the development of the economy in both directions (i.e., acting as a multiplier and accelerator). However, in this article we have focused on the impact of bank loans on the development of the economy. A two-way relationship is also taken into account in the discussion of the results achieved. 


\section{Methods}

This article focuses on examining the relationship between two variables - loans granted and economic development. It is clear that in economic practice, there are a number of factors which affect economic development. We have drafted our analysis on the basis of the ceteris paribus condition, which simplifies the real relationship, but is still suitable for examining the relationship of two variables. In the final discussion, we also define the factors that will otherwise definitely have an impact on the development of the economy.

In this work we have decided to use cointegration analysis; i.e., a method that distinguishes short and long term relationships of time series. This is a relatively modern method used in many of the studies mentioned above and studies of central banks. The result of this is whether the time series are cointegrated or not. Cointegration means that the deviation in the directions of the development of the time series can only be short-term, and there is a limit beyond which the deviation may not continue. The time series are then in equilibrium and have a long-term relationship between them; i.e., they have a common element that can be examined (Arlt \& Arlt, 2007). The advantage of this method over traditional statistical methods is that it identifies any apparent regression.

The analysis model selected is designed in accordance with professional analyses and based on the specific characteristics of the time sequence. The model is created for testing delays of the dependent variable of GDP and stationarity testing, including necessary adjustments of data by differencing. Cointegration is then tested and the final test is to perform Granger causality.

The first step is the need to test the time sequence on the optimum order of delays for the dependent variable GDP. To determine the delay, we used a calculation using Akaike's information criterion (AIC) in the equation below:

$$
\operatorname{AIC}(M)=\ln \sigma_{a}^{2}+2 M / T
$$

where $M$ defines the number of parameters in the model, is the residual variance, and $T$ is the number of observations. The best range of delay is the one where the information criterion reaches the lowest values. The test outputs of the best range of delay are applied in the following tests.
An important prerequisite before testing cointegration is to verify the stationarity of the time sequence being input to the model. Stationarity of the time series is required in order to estimate the regression model. In the case of non-stationary data and modelling using the least squares method, the analysis could have distorted outcomes and could present an apparent regression. In the case of non-stationary time sequence, adjustment should be made using differentiation of the original data. A stochastic process is a timeordered set of random variables, which in theory may be viewed as a function of mean value, variance, covariance and correlation functions. A stochastic process is thus referred to as stationary if the characteristics of the random variable are time constant.

These conditions are formally written as follows (Arlt et al., 2007):

- Mean value function:

$$
\mu_{t}=E\left(X_{t}\right)
$$

- Variation function:

$$
\sigma_{t}=D\left(X_{t}\right)=E\left(X_{t}-\mu_{t}\right)^{2}
$$

- Covariance function:

$$
\gamma(t, t-k)=E\left(X_{t}-\mu_{t}\right)\left(X_{t-k}-\mu_{t-k}\right)
$$

- Correlation function:

$$
\rho(t, t-k)=\frac{\gamma(t, t-k)}{\mu_{t} \sigma_{t-k}}
$$

where $X_{t}$ is the dependent variable, $E\left(X_{t}\right)$ is the mean value $D\left(X_{t}\right)$ is the variance. Stationarity verification is performed using the extended Dickey-Fuller test (ADF test) to test the hypothesis of the existence of a unit root. The test is based on regression of the first differences of the time sequence based on their own delayed values, or the delayed differences. In practice there are three forms of the ADF tests: without a constant, with a constant, and last is with a constant and a trend. The selection is made through the lowest Akaike criteria. Evaluation is based on an assessment of the null hypothesis when it is tested at a significance level of 0.05 , if the time sequence has a unit root. Then we may say that the time sequence is non-stationary. 
Verification of the null hypothesis is evaluated based on the calculated p-values. In testing, we assume that the generating process has the form (Arlt et al., 2007):

$$
\Delta X_{t}=\left(\emptyset_{1}-1\right) X_{t-1}+\sum_{i=1}^{p} \alpha i \Delta X_{t-1}+e_{t}
$$

where we test that $\varnothing=0$ (variable contains a unit root), $X_{t}$ is the dependent variable, $p$ is a delay and $e_{t}$ is a residual component. In the event that it is a non-stationary time sequence, it is necessary to adjust the time sequence by using the first difference. Based on the new values of the time sequence we decide on its stationarity.

If the input time sequences are nonstationary and after adjustment by differentiation, they acquire stationarity of the same order, it is possible to perform a cointegration analysis. When the above conditions are met, the Engle-Granger test (EG test) will be applied on the time sequence to determine the cointegration of the time sequence. This test is based on testing the estimated residues of the cointegrating regression for the presence of a unit root. Cointegration regression will be performed using the smallest squares method. In accordance with the Engle-Granger theories in the next step, random components are tested using the ADF test for the presence of unit roots.

Evaluation of this test is identical to the ADF test mentioned previously, including the selection of the type of regression model by the lowest AIC. We will test the null hypothesis that the time sequences are not cointegrated at a significance level of 0.05 . If the $p$-value for the residues tested is higher than the level of significance of 0.05 , we will not reject the null hypothesis and the tested time sequences are not cointegrated. The variables are then tested for a possible mutual causal link between the tested series on the basis of Granger causation.

The coefficient of determination observed, or the corrected (adjusted) coefficient of determination describes the closeness of the connection. The resulting value can be interpreted in terms of percentage, while indicating what percentage the changes in the response variables are dependent on changes in the explanatory variables. The coefficient of determination indicates the quality of the regression model; expressed more precisely, it indicates what percentage of variance of the response variables is explained by the model and how much remains unexplained.

The final test is to test the causal link between the time sequences, using the Granger causality analysis. Granger defined the concept of causality in the practical use of vector autoregression models (VAR models) for restricted and unrestricted regression. The basic idea is that when a series $X$ affects a series $Y$, then the series $X$ should improve predictions for the series $Y$ (Hendl, 2012). VAR models are based on a comparison of residues of individual models differing in the number of delays. The most suitable model is chosen of a type that has a minimum value of AIC. For the Granger causality test we will use the null hypothesis that the variable $X$ does not affect the variable $Y$ under Granger's conditions. The basic models take the following form (Hušek, 2007):

$$
\begin{aligned}
& Y_{t}=\sum_{i=1}^{p} \alpha_{i} Y_{t-i}+u_{t}, \\
& Y_{t}=\sum_{i=1}^{p} \alpha_{i} Y_{i-r}+\sum_{i=1}^{p} \beta_{i} X_{t-i} u_{t},
\end{aligned}
$$

where $\alpha_{i}$ and $\beta_{i}$ are the coefficients of the variables $X_{t}$ and $Y_{t}$ are time sequence variables, $p$ is the delay and $u_{t}$ is the random component. The first equation estimates the dependent variable based on its own delayed values, the second equation adds to its own delayed values the delayed values of the first variable. The test is conducted using VAR models in which an interaction of up to eight delays is tested. We reject the null hypothesis if the $p$-value is less than the significance level of 0.05 . Hnízdo (2015) further explains the issue in detail.

\section{Data}

Data on loans are taken from the Czech National Bank (ČNB) database. These are loans to non-financial businesses, loans to households, mortgage loans, consumer loans and total loans. All variables are in the form of relative annual change in a quarterly frequency. These data are seasonally adjusted for the time period 2004-2015. The time series is based on financial market developments and changes in the Czech economy. One reason for setting this series is the fact that before 2004 there were significant changes in the banking sector in the Czech Republic, which changed the ownership structure, and the government had intervene to 
stabilise the banking sector and clear the debts of declining large banking companies. The data are shown in the following table. Development of the economy is measured using standard indicators of gross domestic product in the Czech Republic, reported in the statistics of the Czech Statistical Office and also referred to in the database of the Czech National Bank. Again, for comparative purposes, these variables are in the form of relative annual changes in a quarterly frequency. These data are shown in the following figure (Fig. 1).

\section{Fig. 1: Development of GDP and selected types of loans (annual change in \%)}

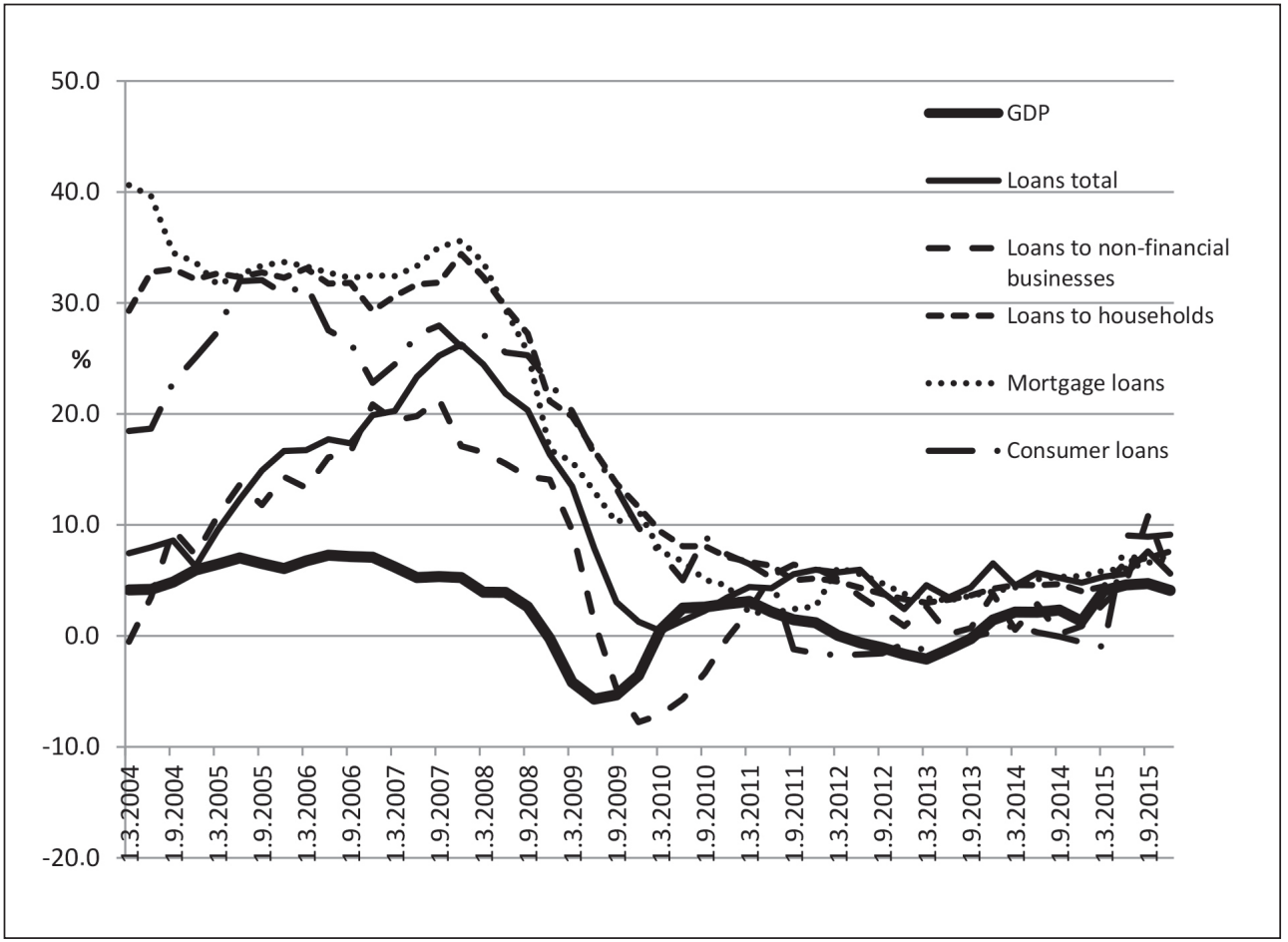

Source: Czech National Bank (2016)

Fig. 1 shows the strong growth of all components of loans granted in 2005-2008, household loans and mortgages from an earlier period. This is related to the rapid growth of the economy, including exports, which are, among other things, driven by investment activity. This is widely funded by loans provided to businesses as well as by mortgage loans. In addition, interest rates have fallen sharply at this time, contributing to a greater willingness particularly among households to incur debts. Another factor is undoubtedly the demographic development, where a significant portion of the population in this period dealt with their housing needs. After 2008, on the other hand, the effects of the financial crisis in developed countries begin to show. These have manifested themselves in the Czech Republic in the economic crisis and the decline in investment and credit activity resulting from a crisis of confidence; i.e., due to the caution of banks in granting loans.

Variables are examined in absolute values and in inter-annual changes. Tab. 1 shows descriptions of the variables used. 


\section{Tab. 1: Definition of the variables used in the analyses}

\begin{tabular}{l|l|l|l}
\multicolumn{1}{c|}{ Variable } & \multicolumn{1}{c|}{ Macroeconomic value } & \multicolumn{1}{c}{ Unit } & \multicolumn{1}{c}{ Source } \\
\hline$Y$ & Gross domestic product & bn. CZK & ČNB \\
\hline$U c$ & Total loans & bn. CZK & ČNB \\
\hline$\Delta Y$ & GDP growth & $\%$ & ČNB \\
\hline$\Delta U c$ & Total loan growth & $\%$ & ČNB \\
\hline
\end{tabular}

Source: own

Tab. 2: Results of optimum order of delay

\begin{tabular}{c|c} 
Order of Delays & AIC for $\Delta \mathbf{Y}$ \\
\hline 1 & 3.41229 \\
\hline 2 & 2.94612 \\
\hline 3 & 2.99098 \\
\hline 4 & 3.03142 \\
\hline
\end{tabular}

\section{Results}

As mentioned above, we are interested in whether there is cointegration among the selected variables. That is, whether the given time series evolve similarly over the long term. This is, from an economic point of view, the underlying idea of the credit channel of the monetary policy transmission mechanism. In the short term, based on the interpretation of the cointegration analysis, some discrepancies may occur.

Based on the model chosen, an optimum order of delay is tested, as well as data stationarity, cointegration test and subsequently the Granger causality test is performed.

For this model, we first determined the optimum delay order on the basis of AIC (according to Formula 1) for GDP in absolute terms as well as inter-annual changes. The results are shown in the Tab. 2.

Based on the lowest value of AIC, we can conclude that for the dependent variable GDP, the optimum delay is that of the second order. The semi-annual delay identified will be reflected in subsequent tests. We will proceed to verify the stationarity of the time sequence. The findings of stationarity in the time series will be made using the extended Dickey-Fuller test (see formula 6). A null hypothesis is used for the ADF test when the time sequences tested are not stationary. Stationarity test results of the series in absolute values and inter-annual changes to GDP and total loans are shown in the Tab. 3.

The results of the ADF unit root test indicate that the original data for all time sequences are non-stationary. Non-stationarity of the time series means that apparent correlation could occur for the correlation analysis. Stationarity for all time sequence was achieved only after their differentiation and the time sequences are therefore integrated in stage I (1); see Part 2 of the Tab. 3.

Based on the results shown above, we can proceed to the cointegration test. The cointegration test is performed using the Engle-Granger test (see formula 2). This test requires non-stationarity of the original time sequence and the same degree of integration. Both conditions are shown in Tab. 3. The null hypothesis for cointegration is that the time sequences tested are not cointegrated. The type of test chosen is based on the lowest value of the Akaike criterion.

Testing cointegration relationships for variables in absolute values is performed using the EG test, where the model is chosen with a constant and trend based on the lowest value of 
Tab. 3: Results of ADF stationarity test for total loans and GDP

\begin{tabular}{|c|c|c|}
\hline Model & p-value & Evaluated result of ADF test \\
\hline \multicolumn{3}{|l|}{ Test with constant } \\
\hline$\Delta \mathrm{Y}$ & 0.6492 & Time sequence is non-stationary \\
\hline$\Delta \mathrm{Uc}$ & 0.7910 & Time sequence is non-stationary \\
\hline$\Delta U p$ & 0.5196 & Time sequence is non-stationary \\
\hline$\Delta U d$ & 0.8450 & Time sequence is non-stationary \\
\hline$\Delta \mathrm{Uh}$ & 0.4006 & Time sequence is non-stationary \\
\hline$\Delta U s$ & 0.8225 & Time sequence is non-stationary \\
\hline \multicolumn{3}{|l|}{ Test with constant } \\
\hline First difference $\Delta \mathrm{Y}$ & 0.01756 & Time sequence is stationary \\
\hline First difference $\Delta U \mathrm{c}$ & 0.00427 & Time sequence is stationary \\
\hline First difference $\Delta U p$ & 0.00007 & Time sequence is stationary \\
\hline First difference $\Delta U d$ & 0.00010 & Time sequence is stationary \\
\hline First difference $\Delta U \mathrm{Uh}$ & 0.00068 & Time sequence is stationary \\
\hline First difference $\Delta \mathrm{Us}$ & 0.00006 & Time sequence is stationary \\
\hline
\end{tabular}

Source: own

\section{Tab. 4: Results of the E-G cointegration test in annual changes}

\begin{tabular}{l|c|c|c|l}
\multicolumn{1}{c|}{ Model } & Variable & AIC & p-value & \multicolumn{1}{c}{ H0: } \\
\hline 2 delays with constant & $\Delta \mathrm{Y}$ & 239.4507 & 0.0693 & Not rejected \\
\hline 1 delay with constant and trend & $\Delta \mathrm{Up}$ & 232.1227 & 0.4894 & Not rejected \\
\hline 1 delay with constant and trend & $\Delta \mathrm{Ud}$ & 231.2742 & 0.2772 & Not rejected \\
\hline 1 delay with constant and trend & $\Delta \mathrm{Uh}$ & 228.4799 & 0.1836 & Not rejected \\
\hline 1 delay with constant & $\Delta \mathrm{Us}$ & 237.2326 & 0.1728 & Not rejected \\
\hline
\end{tabular}

Source: own

AIC, which amounts to $1,121.736$. The resulting calculated values for determining cointegration are listed in the Tab. 4.

Based on tests, we will not reject the null hypothesis of non-cointegration of the time sequence, as the calculated all $p$-values are higher than the specified significance level of 0.05. For this reason, in both cases, the test series is non-cointegrated. In the following test, causality is performed using a VAR model (see formula 3 and 4). For the Granger tests of time causality, a null hypothesis is set, that the development of bank loans does not affect the economic cycle and therefore has no impact on the forecasts of the GDP. Tests are performed for eight quarterly delays, where any causality can be assumed. Test results for inter-annual changes of quarterly values are given in the following table (Tab. 5).

Causal relations of the development of loans to GDP are shown at a significance level of 0.05 at two, four and eight quarterly delays. Based on the calculated $p$-value, it is possible in three cases, to decide to reject the null hypothesis at a significance level of 0.05 . From the economic point of view it means that the development of bank loans in the form of relative annual changes (for total loans) 


\section{Ekonomie}

Tab. 5: Results of Granger causality in annual changes - total loans

\begin{tabular}{l|c|c|c} 
Null hypothesis & Delay & $\mathbf{p}$-value & $\mathbf{H}_{0}:$ \\
\hline$\Delta \mathrm{Uc}$ does not causally act on $\Delta \mathrm{Y}$ & 1 & 0.1843 & Not rejected \\
\hline$\Delta \mathrm{Uc}$ does not causally act on $\Delta \mathrm{Y}$ & 2 & 0.0070 & Rejected \\
\hline$\Delta \mathrm{Uc}$ does not causally act on $\Delta \mathrm{Y}$ & 3 & 0.2816 & Not rejected \\
\hline$\Delta \mathrm{Uc}$ does not causally act on $\Delta \mathrm{Y}$ & 4 & 0.0086 & Rejected \\
\hline$\Delta \mathrm{Uc}$ does not causally act on $\Delta \mathrm{Y}$ & 5 & 0.3925 & Not rejected \\
\hline$\Delta \mathrm{Uc}$ does not causally act on $\Delta \mathrm{Y}$ & 6 & 0.4210 & Not rejected \\
\hline$\Delta \mathrm{Uc}$ does not causally act on $\Delta \mathrm{Y}$ & 7 & 0.1402 & Not rejected \\
\hline$\Delta \mathrm{Uc}$ does not causally act on $\Delta \mathrm{Y}$ & 8 & 0.0176 & Rejected \\
\hline
\end{tabular}

Source: own

causally act within the meaning of Granger causality on the development of GDP, with a certain time lag.

The following table (Tab. 6) shows the results of the Granger causality in quarterly inter-annual changes between developments in loans to non-financial businesses and GDP growth.

Causal relations of the development of loans to non-financial businesses to GDP are shown at a significance level of 0.05 at two, four and eight quarterly delays. Based on the calculated $p$-value, it is possible in three cases, to decide to reject the null hypothesis at a significance level of 0.05 . From the economic point of view it means that the development of bank loans in the form of relative annual changes (for loans to non-financial businesses) causally act within the meaning of Granger causality on the development of GDP, with a certain time lag.
The Tab. 7 shows the results of the Granger causality in quarterly inter-annual changes between developments in loans to households and GDP growth.

Causal relations of the development of loans to households to GDP are shown at a significance level of 0.05 at one, two, four and six quarterly delays. Based on the calculated $p$-value, it is possible in four cases, to decide to reject the null hypothesis at a significance level of 0.05 . From the economic point of view it means that the development of bank loans in the form of relative annual changes (for loans to households) causally act within the meaning of Granger causality on the development of GDP, with a certain time lag.

The Tab. 8 shows the results of the Granger causality in quarterly inter-annual changes between developments in mortgage loans and GDP growth.

\section{Tab. 6: Results of Granger causality in annual changes - loans to non-financial businesses}

\begin{tabular}{l|c|c|c}
\multicolumn{1}{c|}{ Null hypothesis } & Delay & p-value & $\mathbf{H}_{0}:$ \\
\hline$\Delta$ Up does not causally act on $\Delta \mathrm{Y}$ & 1 & 0.5110 & Not rejected \\
\hline$\Delta$ Up does not causally act on $\Delta \mathrm{Y}$ & 2 & 0.0039 & Rejected \\
\hline$\Delta$ Up does not causally act on $\Delta \mathrm{Y}$ & 3 & 0.4321 & Not rejected \\
\hline$\Delta$ Up does not causally act on $\Delta \mathrm{Y}$ & 4 & 0.0172 & Rejected \\
\hline$\Delta$ Up does not causally act on $\Delta \mathrm{Y}$ & 5 & 0.6775 & Not rejected \\
\hline$\Delta$ Up does not causally act on $\Delta \mathrm{Y}$ & 6 & 0.8680 & Not rejected \\
\hline$\Delta$ Up does not causally act on $\Delta \mathrm{Y}$ & 7 & 0.0769 & Not rejected \\
\hline$\Delta$ Up does not causally act on $\Delta \mathrm{Y}$ & 8 & 0.0458 & Rejected
\end{tabular}




\section{Tab. 7: Results of Granger causality in annual changes - loans to households}

\begin{tabular}{l|c|c|c}
\multicolumn{1}{c|}{ Null hypothesis } & Delay & p-value & $\mathbf{H}_{0}:$ \\
\hline$\Delta$ Ud does not causally act on $\Delta \mathrm{Y}$ & 1 & 0.0467 & Rejected \\
\hline$\Delta$ Ud does not causally act on $\Delta \mathrm{Y}$ & 2 & 0.0015 & Rejected \\
\hline$\Delta$ Ud does not causally act on $\Delta \mathrm{Y}$ & 3 & 0.4962 & Not rejected \\
\hline$\Delta$ Ud does not causally act on $\Delta \mathrm{Y}$ & 4 & 0.0012 & Rejected \\
\hline$\Delta$ Ud does not causally act on $\Delta \mathrm{Y}$ & 5 & 0.0507 & Not rejected \\
\hline$\Delta$ Ud does not causally act on $\Delta \mathrm{Y}$ & 6 & 0.0148 & Rejected \\
\hline$\Delta$ Ud does not causally act on $\Delta \mathrm{Y}$ & 7 & 0.1800 & Not rejected \\
\hline$\Delta$ Ud does not causally act on $\Delta \mathrm{Y}$ & 8 & 0.1981 & Not rejected \\
\hline
\end{tabular}

\section{Tab. 8: Results of Granger causality in annual changes - mortgage loans}

\begin{tabular}{l|c|c|c}
\multicolumn{1}{c|}{ Null hypothesis } & Delay & p-value & $\mathbf{H}_{0}:$ \\
\hline$\Delta$ Uh does not causally act on $\Delta \mathrm{Y}$ & 1 & 0.1308 & Not rejected \\
\hline$\Delta$ Uh does not causally act on $\Delta \mathrm{Y}$ & 2 & 0.0031 & Rejected \\
\hline$\Delta$ Uh does not causally act on $\Delta \mathrm{Y}$ & 3 & 0.6881 & Not rejected \\
\hline$\Delta$ Uh does not causally act on $\Delta \mathrm{Y}$ & 4 & 0.0024 & Rejected \\
\hline$\Delta$ Uh does not causally act on $\Delta \mathrm{Y}$ & 5 & 0.9042 & Not rejected \\
\hline$\Delta$ Uh does not causally act on $\Delta \mathrm{Y}$ & 6 & 0.0809 & Not rejected \\
\hline$\Delta$ Uh does not causally act on $\Delta \mathrm{Y}$ & 8 & 0.0461 & Rejected \\
\hline
\end{tabular}

\section{Tab. 9: Results of Granger causality in annual changes - consumer loans}

\begin{tabular}{l|c|c|c}
\multicolumn{1}{c|}{ Null hypothesis } & Delay & p-value & $\mathbf{H}_{0}:$ \\
\hline$\Delta$ Us does not causally act on $\Delta \mathrm{Y}$ & 1 & 0.5113 & Not rejected \\
\hline$\Delta$ Us does not causally act on $\Delta \mathrm{Y}$ & 2 & 0.3063 & Not rejected \\
\hline$\Delta$ Us does not causally act on $\Delta \mathrm{Y}$ & 3 & 0.8347 & Not rejected \\
\hline$\Delta$ Us does not causally act on $\Delta \mathrm{Y}$ & 4 & 0.3192 & Not rejected \\
\hline$\Delta$ Us does not causally act on $\Delta \mathrm{Y}$ & 5 & 0.9337 & Not rejected \\
\hline$\Delta$ Us does not causally act on $\Delta \mathrm{Y}$ & 6 & 0.6910 & Not rejected \\
\hline$\Delta$ Us does not causally act on $\Delta \mathrm{Y}$ & 7 & 0.7653 & Not rejected \\
\hline$\Delta$ Us does not causally act on $\Delta \mathrm{Y}$ & 8 & 0.7132 & Not rejected \\
\hline
\end{tabular}


Causal relations of the development of mortgage loans to GDP are shown at a significance level of 0.05 at two, four and eight quarterly delays. Based on the calculated $p$-value, it is possible in three cases, to decide to reject the null hypothesis at a significance level of 0.05 . From the economic point of view it means that the development of bank loans in the form of relative annual changes (for mortgage loans) causally act within the meaning of Granger causality on the development of GDP, with a certain time lag.

The Tab. 9 shows the results of the Granger causality in quarterly inter-annual changes between developments in consumer loans and GDP growth.

Causal relations of the development of consumer loans to GDP are not shown at a significance level of 0.05 at any quarterly delays. On the basis of the p-values calculated above, we will not reject the null hypothesis at a significance level of 0.05 . From the economic point of view it means that the development of bank loans in the form of relative annual changes (for consumer loans) causally did not act within the meaning of Granger causality on the development of GDP.

More detailed economic commentary on the above calculations, including a discussion of the consistency of our calculations with economic theory and the practical implications, is given in the next chapter.

\section{Discussion}

Based on the calculations shown above, we can conclude that the examined model was statistically confirmed; i.e., development of bank loans in the form of relative annual changes causally operates within the meaning of Granger causality on the development of GDP, with a certain time lag. Thus the set hypothesis is confirmed, namely that the development of bank loans positively correlates with the development of the economy.

The only type of loan where we do not refuse the null hypothesis for any delay are consumer loans. This means that the development of consumer loans does not affect the development of the economy. In economic terms, it is logical mainly from two perspectives. First, the volume of consumer loans in the economy does not reach the same levels as loans to non-financial businesses and mortgage loans, thus they do not have the same impact on economic development. Second, the development of consumer loans responds more to the development of the economy. Businesses require consumer loans in times when the economy is thriving or is expected to continue to thrive and economic entities will be able to repay the loans.

For all other types of loans - loans to nonfinancial businesses, loans to households, mortgage loans and total loans - the statistically most significant time lag is two and four quarters, when we reject the null hypothesis. For three types of loans, excluding mortgages, a time delay of 8 quarters is statistically significant. A time delay of the effect of loans on economic development of two four quarters best corresponds to the expectations of the transmission mechanism of monetary policy. Central banks typically consider the time delay of the effectiveness of their monetary/policy instruments in an interval of 4-6 quarters.

Conclusions demonstrated by our calculations correspond to current standard economic thinking. This is also represented in the majority of the articles stated above see the first group of authors in the section Theoretical Basis. Of course the authors worked with various defined variables, however, the findings of their studies and ours are essentially the same. Other authors who came to the same conclusions from the viewpoint of the effects of various types of loans are Ermisoglu et al. (2013) and Armeanu et al. (2015), who found that business loans have a higher impact on GDP growth than loans to households. It is a question of the length of the loans and the resulting investment in businesses. Furthermore, our results concerning mortgage loans were consistent with the findings of Kelly et al. (2013), where a dependence was demonstrated that the expansion of mortgage loans also promotes the growth of GDP. On the other hand, in the Czech Republic today risks are beginning to appear associated with a higher rate of lending, which corresponds more to the conclusions of those economists who say that a negative relationship exists between lending growth and economic performance, namely in the form of a risk of over-indebtedness (Leitao et al., 2012; Ibanez et al., 2014). Not only in the Czech Republic is there mainly an increase in the provision of $100 \%$ mortgages; i.e., a situation where a mortgage loan is provided in the amount of the secured real estate. Another 
issue may be the growth of credit card loans, however, this issue has not been substantially quantified in the Czech Republic.

From the point of view of the practical use of our results, we can recommend the central bank to adequately influence the amount of money in circulation issued through commercial credits. We have shown that, apart from consumer credit, all other analysed loans have a certain impact on the development of the economy, and always with a certain time lag. This confirms the functioning of the credit channel of the transmission mechanism in the Czech Republic.

Leaving aside the minor studies showing either negative or no relationship between loans and economic development, we must also mention the important factors that undermine the positive relationship of the variables examined.

We can divide these into economic and uneconomic. Among the economic factors we may definitely include active monetary and fiscal policies. Both of these policies under conditions such as those of the Czech Republic and under the conditions of developed countries in recent years have recently been very proactive. Monetary policies in response to the financial crisis have employed so-called Unconventional monetary tools in three different forms. The first is that of quantitative easing, secondly, setting negative interest rates - both with indirect influence on a weakening exchange rate. The third form was a direct weakening of local currencies through foreign exchange interventions, which was implemented by the central bank in the Czech Republic. A more detailed comparison of all these tools was made by Černohorská and Flosová (2014), who summarises that the greatest benefits of this policy, outside the Czech Republic, are increased liquidity of financial markets, but it is not a sufficient condition to resolve the fundamental problems. However, the use of these tools has led to the promotion of economic growth. Fiscal policies of developed countries have also responded to the financial crisis with a huge degree of expansion to restrain the decline of the economies. The Czech Republic was the exception in this regard, because the first reaction of the government at the time was a significant tightening of fiscal conditions in the form of an increase in indirect taxes and a reduction in government spending, which led to a relatively sharp economic decline in the early years. Later however, another political administration implemented, and is still implementing, an expansionary fiscal policy. Another economic factor is the dependence of the domestic non-banking entities on domestic financial resources. The vast majority of domestic entities still procure loans from domestic banks (particularly households). A certain percentage of loans to businesses come from foreign banks, but in the context of the entire Czech banking sector, this is not particularly striking. The problem was rather lower functionality of the credit transmission mechanism away from the central bank to commercial banks. Owing to the systemic liquidity surplus, banks had little interest in newly issued money from the Czech National Bank, as they had no way to assess it.

Among the most important non-economic factors we must include the confidence of businesses in future development. This confidence is strongly influenced by the statements of politicians. This is also related to the political cycle when politicians implement an expansionary fiscal policy before an election, basically regardless of the needs of the economy (for more, see Černohorská \& Černohorský, 2009). Conversely, after an election, they implement unpopular measures such as raising taxes and reducing government spending. In the Czech Republic, except for a brief period of restrictive fiscal policy in and after 2009, a rather expansionary fiscal policy has been exercised.

Based on the results of our study and related comments, it is necessary to continue with further research, especially from the point of view of the bi-directional impact of the variables in question, the inclusion of other variables, including the extension to other countries with a longer time series of suitable indicators.

\section{Conclusion}

The aim of this article was to examine the impact of the development of different types of loans in the banking sector on economic development. The main idea of the article is based on the hypothesis that economic performance increases with the growth of the rate of various types of loans. We investigated the validity of this hypothesis using selected statistical and mathematical methods. The model is built on testing delays dependent 
the variable of GDP, and the stationarity test, including the necessary adjustments of data by differencing. Cointegration is then tested and the final test is to perform Granger causality. We began with data from the Czech Statistical Office or the Czech National Bank from the period 2004-2015. All figures are in the form of relative annual changes for each quarter. The result of our calculations confirms that different types of bank loans have an impact on the development of the economy as measured by GDP development. The only exception is consumer loans, where this relationship was not confirmed. We explain it rather that consumer loans are dependent on economic development. Other types of loans - loans to non-financial businesses, loans to households, mortgage loans and total loans - influence the development of gross domestic product. The statistically most significant time lags appear to be two and four quarters, which correspond to the practical considerations of monetary policy, instrument settings, and their effect on the economy. Of course it is necessary to take into account a variety of economic and non-economic factors which partially dissipate this influence.

This research was supported by the Czech Science Foundation (Project No. GA 17-02509S).

\section{References}

Arlt, J., \& Arltová, M. (2007). Ekonomické časové rady. Praha: Grada.

Armeanu, D., Pascal, C., Poanta, D., \& Doia, C. A. (2015). The Credit Impact on the Economic Growth. Theoretical and Applied Economics, 22(1), 5-14.

Banu, I. M. (2013). The Impact of Credit on Economic Growth in the Global Crisis Context. In S. Marginean et al. (Eds.), Procedia Economics and Finance (pp. 25-30). Sibiu: University of Sibiu.

Bencivenga, V., \& Smith, B. (1993). Some Consequences of Credit Rationing in an Endogenous Growth Model. Journal of Economic Dynamics and Control, 17(1-2), 97-122.

Beck, T., \& Levine, R. (2004). Stock Markets, Banks, and Growth: Panel Evidence. Journal of Banking \& Finance, 28(3), 423-442. doi:10.1016/S0378-4266(02)00408-9.

Beck, T., Levine, R., \& Loayza, N. (2000). Finance and the Sources of Growth. Journal of financial economics, 58(1), 261-300. doi:10.1016/S0304-405X(00)00072-6.

Černohorská, L., \& Černohorský, J. (2009). Politický cyklus v České republice. Scientific papers of the University of Pardubice. Series $D$, 14(Spec. Ed.), 27-35.

Černohorská, L., \& Flosová, H. (2014). Monetary Policy of Central Banks in the Times of Financial Crises. In Conference on Political Sciences, Law, Finance, Economics and Tourism. Vol. 2. Conference Proceedings (pp. 495-502). Sofia: SGEM.

Černohorský, J. (2015). Koncentrace a ziskovost na bankovním trhu České republiky. Scientific Paper of the University of Pardubice, Series $D, 22(3), 30-41$.

Cetorelli, N., \& Gambera, M. (2001). Banking Market Structure, Financial Dependence and Growth: International Evidence from Industry. The Journal of Finance, 56(2), 617-648. doi:10.1111/0022-1082.00339.

Czech National Bank. (2016). ARAD Time Series System. Praha: Czech National Bank. Retrieved February 28, 2016, from http://www. cnb.cz/docs /ARADY/HTML/popis.htm.

De Gregorio, J., \& Guidotti, P. (1995). Financial Development and Economic Growth. World development, 23(3), 433-448. doi:10.1016/0305-750X(94)00132-I.

Ermişoğlu, E., Akcelik, Y., \& Oduncu, A. (2013). GDP Growth and Credit Data [MPRA Paper No. 46613]. Ankara: Central Bank of the Republic of Turkey. Retrieved February 26, 2016, from https://core.ac.uk/download/pdf/12036388.pdf.

Friedman, M. (1968). The Role of Monetary Policy. The American Economic Review, 58(1), 1-17.

Friedman, M., \& Schwartz, A. J. (1963). A Monetary History of the United States, 1867-1960. 9th ed. Princeton: Princeton University Press.

Hendl, J. (2012). Přehled statistických metod: analýza a metaanalýza dat. Praha: Portál.

Hnízdo, M. (2016). Bankovní úvěry a hospodářský cyklus. Pardubice: Univerzita Pardubice.

Holtemöller, O. (2004). A monetary vector error correction model of the Euro area and implications for monetary policy. Empirical Economics, 29(3), 553-574. doi:10.1007/ s00181-004-0198-4.

Hušek, R. (2007). Ekonometrická analýza. Praha: Oeconomica.

Ibáñez-Hernández, F. J., Peña-Cerezoa, M. Á., \& Araujo, A. (2015). Countercyclical 
capital buffers: credit-to-GDP ratio versus credit growth. Applied Economics Letters, 22(5), 385390. doi:10.1080/13504851.2014.946174.

Kaufmann, S., \& Kugler, P. (2010). A Monetary Real-Time Conditional Forecast of Euro Area Inflation. Journal of Forecasting, 29(4), 388-405. doi:10.1002/for.1133.

Kelly, R., McQuinn, K., \& Stuart, R. (2013). Exploring the Steady-State Relationship between Credit and GDP for a Small Open Economy: the Case of Ireland [ECB Working Paper 1531]. Frankfurt: European Central Bank. Retrieved February 28, 2016, from https://ssrn. com/abstract $=2240169$.

Koivu, T. (2002). Do Efficient Banking Sectors Accelerate Economic Growth in Transition Countries [Discussion Paper No. 14/2002]. Helsinki: Bank of Finland. Retrieved February 26, 2016, from https://papers.ssrn. com/sol3/papers.cfm?abstract_id=1015710. doi:10.2139/ssrn.1015710.

Leitão, N. C. (2012). Bank Credit and Economic Growth: A Dynamic Panel Data Analysis. Economic Research Guardian, 2(2), 256-267.

Levine, R. (2005). Finance and Growth: Theory and Evidence. Handbook of Economic Growth (pp. 865-934).

Levine, R., \& Zervos, S. (1998). Stock Markets, Banks, and Economic Growth. The American Economic Review, 88(3), 537-558.

Lucas, R. E., Jr. (1988). On the Mechanics of Economic Development. Journal of Monetary Economics, 22(1), 3-42. doi:10.1016/03043932(88)90168-7.
Mian, A. R., Sufi, A., \& Verner, E. (2015). Household Debt and Business Cycles Worldwide [NBER Working Papers No. 21581]. Cambridge, MA: National Bureau of Economic Research. Retrieved February 28, 2016, from https://academic.oup.com/qje/articleabstract/3854928/Household-Debt-andBusiness-Cycles-Worldwide. doi:10.1093/qje/ qjx017.

Mishkin, F. S. (2016). The Economics of Money, Banking and Financial Markets (11th ed.). Boston: Pearson.

Robinson, J. (1952). The Generalization of the General Theory. In The rate of interest and other essays (pp. 67-146). London: Macmillan.

Schumpeter, J. A. (1912). Theorie der wirtschaftlichen entwicklung. Leipzig: Dunker \& Humblot.

Takáts, E., \& Upper, C. (2013). Credit and Growth after Financial Crises [BIS Working Paper No 416]. Basel: Bank for International Settlements. Retrieved February 26, 2016, from https://papers.ssrn.com/sol3/papers. cfm?abstract_id=2375674.

Ing. Jan Černohorský, Ph.D. University of Pardubice

Faculty of Economics and Administration Institute of Economic Sciences jan.cernohorsky@upce.cz 


\section{Abstract}

\section{TYPES OF BANK LOANS AND THEIR IMPACT ON ECONOMIC DEVELOPMENT: A CASE STUDY OF THE CZECH REPUBLIC}

\section{Jan Černohorský}

This article aims to evaluate the impact of the development of different types of loans in the banking sector on economic development. We will begin with the hypothesis that economic performance increases with the growth of the rate of various types of loans. We will first look at research of current scientific knowledge in respect to bank loans and economic development. The basic idea of this article is the hypothesis described above, determined on the basis of standard economic findings and based on the results of a majority of related studies. The development of loans provided can be quantified based on data from the Czech National Bank as total loans and divided into loans to non-financial companies and households, as well as mortgage loans and consumer loans. The development of the economy can also be quantified using data from the Czech Statistical Office on the development of the gross domestic product. The period selected is the years 2004-2015. To determine the relationships between selected variables, we have used statistical methods that respect the specific characteristics of the selected time series, namely the Engle-Granger causality test. Prior to testing, it was necessary to adjust the data as stationary and then test cointegration. An optimum order delay was also determined using the Akaike information criterion. The calculated results, except for consumer loans, confirm the hypothesis regarding the positive impact of the rate of loans provided on economic growth, particularly with a six-month time lag. We have obtained results that correspond to standard economic knowledge and results of most previous studies.

Key Words: Banks, bank loans, economic cycle, Engle-Granger causality.

JEL Classification: G34, M12.

DOI: 10.15240/tul/001/2017-4-003 